\title{
POR UM CONSTANTE REPENSAR DE NOSSAS VISÕES SOBRE LÍNGUA: REVISITANDO O CONCEITO DE POLÍTICA LINGUÍSTICA
}

(By a constant rethink of our views about language: revisiting the concept of language policy)

\author{
Djane Antonucci Correa ${ }^{1}$ \\ (Universidade Estadual de Ponta Grossa - UEPG) \\ Taís Regina Güths ${ }^{2}$ \\ (Universidade Estadual de Ponta Grossa - UEPG)
}

\begin{abstract}
This article aims to revisit the concept of language policy in order to emphasize the need to our views about language are always rethought and problematized, considering the role of language policy agent. For that, a) we discuss the history of language policies in Brazil, passing questions related to language teaching, $b$ ) we reflect on how it was building the ideal of monolingualism, and c) we seek to understand how policies can go beyond the construction of an ideal nation based on linguistic unity.

Key-words: Language teaching; Monolingualism; Language(s) Policy(ies).
\end{abstract}

\section{RESUMO}

Este artigo objetiva revisitar o conceito de política linguística, de modo a enfatizar a necessidade de que nossas visões sobre língua sejam sempre repensadas e problematizadas, considerando o papel do agente de política linguística. Para isso, a) discutimos a história das políticas linguísticas no Brasil, perpassando questões voltadas ao ensino de língua, b) refletimos sobre como se foi construindo o ideal de monolinguismo, e c) buscamos perceber como políticas podem ir além da construção de um ideal de nação baseado na unidade linguística.

Palavras-chave: Ensino de língua; Monolinguismo; Política(s) Linguística(s).

\section{INTRODUÇÃO}

Há algum tempo, nos estudos de área de Linguística Aplicada, temos nos deparado com trabalhos que consideram a língua em seu caráter político, perpassando, dessa forma, discussões sobre política linguística. Para exemplificar, podemos citar algumas publicações recentes, como o livro organizado por Christine Nicolaides et al, intitulado Política $e$ Políticas Linguísticas, lançado em 2013, e o livro organizado por Djane Antonucci Correa, intitulado Política Linguística e Ensino de Língua, publicado em 2014, além do clássico livro de Louis-Jean Calvet chamado As políticas linguísticas, em cujo prefácio o pesquisador

\footnotetext{
${ }^{1}$ Professora do Departamento de Estudos da Linguagem, do Mestrado em linguagem, identidade e subjetividade e coordenadora do Laboratório de estudos do texto - LET da UEPG. Área de atuação: Linguística Aplicada, dedicando-se aos estudos críticos da linguagem escrita e as relações desta com ensino e aprendizagem de língua, política linguística e pragmática. djaneantonucci@gmail.com

${ }_{2}^{2}$ Mestre em Linguagem, Identidade e Subjetividade pela Universidade Estadual de Ponta Grossa (UEPG). Professora da rede estadual de ensino do Paraná e do Departamento de Estudos da Linguagem da UEPG. Atua na área de Linguística Aplicada, dedicando-se aos seguintes temas: ensino e aprendizagem de línguas, línguas minoritárias, pragmática e política linguística. guths.tais@gmail.com 140
} 
Gilvan Müller Oliveira ressalta a "virada político-linguística" pela qual temos passado nos estudos linguísticos. Tais publicações mostram como é atual a necessidade de nos debruçarmos sobre a estreita relação existente entre política(s) linguística(s) e ensino de língua, seja língua materna ou estrangeira.

No primeiro livro citado acima, Rajagopalan (2013) propõe uma discussão em torno da pergunta: "Política Linguística: do que é que se trata, afinal?”, mostrando-nos que ainda há certa indefinição sobre essa questão, pois, segundo ele, esse termo é, muitas vezes, confundido com militância linguística em prol de uma língua, quando, na verdade, essa terminologia abarca muitas outras ações relacionadas à língua, algumas, inclusive, que buscam coibir o uso de determinada língua. Tendo esse cenário em vista é que propomos, neste artigo, que revisitemos esse conceito, o qual, cada vez mais, está presente nos estudos sobre língua, assim trazemos alguns apontamentos e questionamentos necessários para o pensar sobre a complexidade que há nas políticas das esferas in vivo e in vitro (CALVET, 2007) bem como na relação entre essas duas esferas de gestão.

Esclarecemos que, apesar de apontarmos para um revisitar de conceitos, estes são vistos como entidades necessárias, uma vez que "estão no centro da atividade cognitiva" (HARDY-VALLÉE, 2013: 17), porém nunca acabadas, por isso, nossa busca por problematizar esse conceito e nossa certeza de que nunca chegaremos a conceitos estanques e fechados, que dêem conta da realidade que é sempre híbrida.

Para isso, propomos uma incursão histórica que nos levará a compreender melhor as políticas linguísticas em diferentes períodos da história de nosso país, desde a colonização até o período atual. Assim, propomos uma discussão sobre essa busca por um ideal monolíngue por meio de repetidas políticas linguísticas por parte do Estado - o que nos permite perceber o importante papel das políticas linguísticas na própria construção do conceito hegemônico de nação.

Nessa busca por propiciar um repensar de noções ligadas aos estudos voltados à política linguística, nosso artigo se divide da seguinte forma: primeiramente, apresentamos algumas discussões em torno do conceito de política linguística, em seguida, seguimos as trilhas de diferentes políticas linguísticas, buscando perceber como se relacionam com o ensino de línguas, desse modo, na sequência, propomos uma discussão sobre políticas que vão além dessa busca por um ideal monolíngue, e, para finalizar, apresentamos algumas considerações finais. 


\section{POLÍTICA LINGUÍSTICA: ALINHANDO DISCUSSÕES}

Para discutir o que seria política linguística, partimos, inicialmente, das afirmações de Rajagopalan (2013), segundo o qual, como já afirmamos, ainda há muita confusão e indefinição sobre o que significa esse termo. De acordo com ele,

Muitas vezes, tenho a impressão de que, quando as pessoas se referem à política linguística, elas querem dizer algo como 'militância linguística' em prol de línguas na beira de extinção, línguas ou variedades que são objetos de discriminação ou descaso etc., [...]. Sem sombra de dúvida, a militância faz parte daquilo que chamamos de política linguística; mas é importante frisar que ela faz apenas uma pequena parte, ainda que vital. O campo de política linguística encobre muito mais do que a militância linguística. (RAJAGOPALAN, 2013,p. 19).

A fim de tratar de política linguística nesse sentido que vai além da militância, em grande parte da discussão, teremos como base Calvet (2002; 2007), autor esse cujas publicações são bastante relevantes dentro dessa área de estudo. Porém, desde já esclarecemos que muitos dos conceitos trazidos por esse autor devem ser problematizados, uma vez que conceitos fechados não devem ser vistos como pontos de chegada, mas, sim, como pontos de partida.

Segundo Calvet (2007), a intervenção humana na língua sempre existiu, pois sempre houve quem buscasse legislar e ditar o uso correto de determinada língua, "De igual modo, o poder político sempre privilegiou essa ou aquela língua, escolhendo governar o Estado numa língua ou mesmo impor à maioria a língua de uma minoria. (CALVET, 2007, p. 11).

É importante que vejamos essa opção do governo por determinada língua como um passo necessário na construção de uma nação entendida, nos termos de Anderson (2008), como uma nação imaginada, aquela que é "imaginada como sendo intrinsecamente limitada e, ao mesmo tempo, soberana" (ANDERSON, 2008, p. 32). Isso porque, para esse autor, a nação está relacionada a um sentimento de filiação entre os membros dessa comunidade, de modo que, “[...] desde o começo, a nação foi concebida na língua, e não no sangue, [...] as pessoas podem ser 'convidadas a entrar' na comunidade imaginada”. (ANDERSON, 2008, p. 204). Por o autor trazer as palavras "convidadas a entrar" entre aspas, podemos perceber que isso não deve ser visto como algo isento de conflito, pois as grandes decisões que ocorreram em 
nosso país referentes às relações entre as línguas e a sociedade - modo como Calvet (2007) define políticas linguísticas que será expandido na sequência - estão permeadas por conflitos

Ainda para Calvet (2007), não é possível falar de política linguística sem falar de planejamento linguístico ${ }^{3}$, o qual é visto, por ele, como sendo a implementação das políticas. Nesse sentido, entendemos que "o planejamento linguístico agirá sobre o ambiente, para intervir no peso das línguas, na sua presença simbólica”. (CALVET, 2007, p. 73). Há uma ressalva a ser feita já no início da discussão, para esse autor, qualquer grupo pode elaborar uma política linguística, porém "apenas o Estado tem o poder e os meios de passar ao estágio do planejamento, de pôr em prática suas escolhas políticas”. (CALVET, 2007, p. 20-21).

Assim, é possível perceber que todos eles dependem de escolhas que nunca são neutras. Além disso, pudemos perceber, pelo modo como Calvet (2007) faz sua discussão, que essas escolhas dependem de um poder político para serem postas em prática. Nesse sentido, ressaltamos que muitas das discussões de Calvet em seu livro "As Políticas Linguísticas" se referem a políticas que dependem de um poder como o do Estado para serem concretizadas. Contudo, o mesmo autor faz uma distinção que, para nós, é essencial, quando trata "do 'in vivo' para o 'in vitro"”. Desde já, esclarecemos que buscamos problematizar essa relação que Calvet (2007) estabelece, ao dizer que, de uma política in vivo, chegamos a uma política in vitro, pois, como veremos, nem sempre essa teoria se concretiza na prática.

Sobre essa terminologia, Calvet (2007) explica há dois tipos de gestão das situações linguísticas, a in vivo e a in vitro. A primeira delas "refere-se ao modo como as pessoas resolvem os problemas de comunicação com que se confrontam cotidianamente" (CALVET, 2007, p. 69). Entre os exemplos citados pelo autor, destacamos a criação de línguas aproximativas, a criação de línguas veiculares ou a promoção de determinada língua já existente, a criação de palavras - desde que isso não tenha relação com uma decisão oficial, sendo, portanto, o produto de uma prática social. Já a gestão in vitro é a abordagem dos problemas referentes ao uso das línguas pelo poder oficial. Isso porque essa gestão ocorre, de acordo com Calvet (2007), quando

em seus laboratórios, linguistas analisam as situações e as línguas, as descrevem, levantam hipóteses sobre o futuro das situações linguísticas,

\footnotetext{
${ }^{3}$ Vale destacar que, segundo Rajagopalan (2013), o termo política linguística em português encobre tanto as decisões no nível mais geral quanto as atividades para implementá-las, sendo que o termo planejamento linguístico se refere justamente a essa segunda acepção. Porém, não há um termo que se refira exclusivamente à primeira acepção, diferentemente do que ocorre em inglês, em que essas duas fases são designadas por palavras distintas: language policy e language planning.
} 
propostas para solucionar os problemas e, em seguida, os políticos estudam essas hipóteses e propostas, fazem escolhas, as aplicam. (CALVET, 2007, p. 70).

Gostaríamos, nesse momento, de explicar que essa definição deve ficar em suspenso, pois a discutiremos melhor na sequência, mas adiantamos que, quando virmos a trajetória das políticas linguísticas e algumas contribuições de Rajagopalan (2013) sobre o que são políticas linguísticas, poderemos questionar algumas dessas afirmações.

Essa divisão entre políticas in vivo e in vitro também está presente nas discussões de outros autores, mesmo que não necessariamente utilizem esses termos. Uma dessas autoras é Maher (2013), que, ao tratar de alguns mitos que circundam o campo das políticas linguísticas, afirma que muitos ainda acreditam que as políticas linguísticas seriam sempre explícitas e partiriam do governo. A autora esclarece que

Políticas linguísticas podem também ser arquitetadas e colocadas em ação localmente: uma escola ou uma família, por exemplo, podem estabelecer - e colocar em prática - planos para alterar uma certa situação (sócio) linguística [...].(MAHER, 2013, p. 120).

Desse modo, quando se considera que políticas linguísticas não se restringem às decisões do Estado, temos uma gama muito maior de ações que podem ser consideradas. Altenhofen (2013) traz como exemplos:

a proibição de uso de uma língua no currículo escolar, a decisão da carga horária para o ensino de línguas adicionais no currículo, a decisão sobre as línguas estrangeiras solicitadas nas provas de vestibular, a decisão de um sacerdote para realizar um sermão na língua da comunidade, a decisão de um estabelecimento comercial para contratar empregados que 'falem determinada língua'[...], a opção na denominação de uma entidade ou estabelecimento comercial, a decisão de uma prefeitura por fixar placas de sinalização bilíngues [...]. (ALTENHOFEN, 2013, p. 103).

Vemos nessa citação que as políticas não partem exclusivamente do Estado, pois todos nós movemos políticas linguísticas, assim, pelos exemplos de Altenhofen (2013), percebemos que outras instituições também são responsáveis pela gestão da língua, como a igreja, estabelecimentos de comércio, além da própria família. Além disso, percebemos que as escolhas que acontecem na esfera in vivo não podem ser desconsideradas, uma vez que muitas delas ocupam um espaço relevante no pensar sobre a língua. Por isso, ainda em se tratando dessa distinção ou mesmo da relação entre esses dois modos de gestão trazidos por Calvet (2007), apresentamos alguns direcionamentos amparados em Rajagopalan (2013). 
Apesar de não termos como foco a palavra política sem seu adjetivo linguística, é importante frisar algumas contribuições da discussão desse termo a partir de Rajagopalan (2013) para pensarmos na relação entre políticas in vivo e políticas in vitro. Segundo este autor, o termo política abriga diferentes acepções e ênfases, entre as quais é imprescindível que pensemos na questão da escolha. Isso porque "Todo gesto de cunho político envolve uma questão de escolha - escolha entre diferentes alternativas que se apresentam" de forma que tanto no nível das decisões que são tomadas nas altas instâncias do poder quanto no nível das práticas linguísticas locais, aquelas que ocorrem entre os cidadãos comuns, "a questão da escolha salta aos olhos quando se discute a operacionalidade da política linguística". (RAJAGOPALAN, 2013, p. 34-35).

Rajagopalan (2013) explica que, em se tratando de escolha, o papel do agente é fundamental, sendo também de extrema importância quando se discute política linguística. $\mathrm{O}$ agente, segundo ele, é aquele que se distingue pela sua vontade de se auto-afirmar e marcar o seu posicionamento, mesmo que não venha a obter grande sucesso em sua ousadia. Nas palavras do autor, "Podemos dizer que ele é um sujeito que conseguiu furar o cerco da estrutura que o esmagava e tolhia a sua autonomia e desejo e direito de agir" (RAJAGOPALAN, 2013, p. 36). Essa noção de agente é fundamental para entendermos como as políticas linguísticas são arquitetadas, por isso, ressaltamos que, por mais que os agentes estejam associados às políticas de baixo para cima, eles podem ser aqueles que vão de encontro às políticas do Estado, mas também podem ser aqueles que reafirmam as políticas de Estado. Desse modo, ressaltamos que o professor tem um papel fundamental como agente de políticas linguísticas, pois esse está o tempo todo tomando decisões sobre qual língua/norma ensinar/cobrar e sobre como trabalhar tendo em vista a variação linguística e noções de adequação, por exemplo.

Além disso, não podemos desconsiderar os conflitos que podem existir entre a gestão in vivo e a gestão in vitro. Conforme dispõe Calvet (2007), "Essas duas abordagens são extremamente diferentes e suas relações podem, às vezes, ser conflituosas se as escolhas in vitro forem no contrapé da gestão in vivo ou dos sentimentos linguísticos dos falantes." (CALVET, 2007, p. 70). Isso porque, ainda de acordo com o mesmo autor, diferentemente do que ocorre na gestão in vivo, na qual a mudança ocorre de baixo para cima, "a gestão in vitro deve, por sua vez, se impor aos falantes e, para isso, o Estado dispõe essencialmente da lei”. (CALVET, 2007, p. 74-75). 
Desse modo, os Estados intervêm nos comportamentos linguísticos dos falantes e nos usos das línguas, assim, Calvet (2007) afirma que as políticas linguísticas são geralmente repressoras, precisando da lei para se impor, concluindo que, sem suporte jurídico, não há planejamento linguístico, existindo inúmeras concepções de leis linguísticas. Há aquelas que têm como foco a forma da língua, como a fixação de uma grafia; há aquelas que se ocupam do uso que as pessoas fazem da língua, aquelas que ditam qual língua deve ser falada em determinada sociedade, abarcando também a definição da língua nacional; e há aquelas que buscam a defesa das línguas, como por meio de uma maior promoção para determinada língua de modo a protegê-la.

A partir disso, tendo em vista os modos como os Estados buscam interferir no uso das mais variadas línguas e também as ações que partem da esfera in vivo, não há como contestar uma das contribuições de Anderson (2008) quando esse autor diz que "a coisa mais importante quanto à língua é sua capacidade de gerar comunidades imaginadas, efetivamente construindo solidariedades particulares. (ANDERSON, 2008, p. 189, grifos do autor). Desse modo, entendemos também o porquê de, apesar de haver políticas linguísticas em prol das línguas minoritárias, Calvet (2002) explicar que há problemas de ordem democrática, como quando esse afirma que, "há um reduzido número de planejadores e um grande número de planejados aos quais raramente se pergunta a opinião". (CALVET, 2007, p. 159). Sobre essa questão, Calvet (2002) traz um aviso, quando diz: "não deixar os que tomam decisões fazer o que lhes der na telha”. (CALVET, 2002, p. 148). Todavia, ele não problematiza e aprofunda de que modo o povo pode efetivamente se fazer ouvir e não deixar que tomem decisões por ele, uma vez que, em muitos momentos, conforme veremos, as consequências para quem vai de encontro a decisões sobre língua tomadas pelo governo podem ser muito sérias.

Outra afirmação de Calvet (2007) que deve ser discutida a fundo é a de que, segundo ele, a tendência seria o planejamento in vitro "imitar" o planejamento in vivo. Por isso, o tópico do livro ${ }^{4}$, conforme já mencionado, que trata dessa distinção é "Do 'in vivo' para o 'in vitro"”.

A partir de pesquisas realizadas em uma comunidade de imigração ${ }^{5}$, em que discutimos a relação entre essas duas esferas por meio do acompanhamento de projetos

\footnotetext{
${ }^{4}$ CALVET, Louis-Jean. As políticas linguísticas. São Paulo: Parábola Editorial: IPOL, 2007.

${ }^{5}$ GÜTHS, Taís Regina. Olhares para as políticas linguísticas no município de Itaiópolis - SC: entre o in vivo e o in vitro. 2015. 210 f. Dissertação (Mestrado) - Curso de Mestrado em Linguagem, Identidade e Subjetividade, Universidade Estadual de Ponta Grossa, Ponta Grossa, 2015. 146
} 
movidos por políticas linguísticas de manutenção de uso da língua de imigração e a partir de leituras sobre a história das políticas linguísticas em nosso país, percebemos que o mais adequado seria tratarmos de políticas linguísticas entre o in vivo e o in vitro, por constatarmos que não podemos ver essas duas formas de gestão como separadas, da mesma forma que não podemos entender a gestão in vitro como apenas uma imitação da gestão in vivo - mesmo que o autor fale que é uma tendência isso acontecer. Veremos que, na história das políticas linguísticas em nosso país, o que houve, em muitos momentos, foi uma imposição. Além disso, entendemos que as duas formas de gestão ocorrem simultaneamente, assim ambas exercem influência uma sobre a outra.

Como contraponto a essa visão de Calvet (2007), Maher (2013), ao tratar dos mitos em relação às políticas linguísticas, explica que um deles é acreditar que essas sempre buscam soluções para “problemas linguísticos". Isso é um mito porque, segundo a autora,

o que se almeja, quase sempre, é a manipulação das identidades dos falantes de uma dada língua, seja no sentido de enaltecê-las ou de denegri-las. Há uma relação profunda, estreita e visceral entre políticas linguísticas e políticas de identidade. [...] o estabelecimento de políticas linguísticas não são nunca processos neutros, apolíticos ou isentos de conflito [...]. (MAHER, 2013, p. 120-121).

Vemos, com isso, que a própria noção do que seriam "problemas linguísticos" deve ser problematizada, questionando: são problemas para quem? Isso porque, de acordo com a autora, o que se busca, por meio de muitas políticas linguísticas, é manipular a identidade dos falantes com determinado objetivo, assim como ocorreu recorrentemente nas políticas linguísticas de nosso país. Salientamos que essa relação entre identidade e língua será estabelecida no próximo tópico, porém achamos oportuno, neste momento, esclarecer que as políticas linguísticas têm, sim, uma relação muito estreita com questões de identidade.

Outro ponto da teoria de Calvet (2007) que gostaríamos de ressaltar é que ele afirma, como apresentamos anteriormente, que a gestão in vitro ocorreria primeiramente com os linguistas analisando as situações e as línguas, para depois levantar propostas para solucionar "os problemas" - mais uma vez temos a questão da resolução de problemas que é considerada mito na opinião de Maher (2013) como discutimos acima.

Nesse momento, trazemos à discussão a questão do papel dos linguistas nas políticas linguísticas. Para isso, primeiramente salientamos que, conforme veremos no próximo tópico, não foram linguistas os responsáveis por definir as políticas in vitro em nosso país. Portanto, 
não podemos tomar essa afirmação de Calvet (2007) como algo que seria a regra para o estabelecimento e para a execução de políticas in vitro.

Sobre essa questão, Rajagopalan (2013) tem um posicionamento que consideramos coerente. Segundo ele,

a política linguística não tem nada a ver com a linguística; ela tem tudo a
ver, isto sim, com a política, entendida como uma atividade na qual todo
cidadão - todos eles, sem exceção - tem o direito e o dever de participar em
condições de absoluta igualdade, sem se importar com classe econômica,
sexo, orientação sexual, idade, escolaridade, e assim por diante. E não só o
direito de expressar suas opiniões livremente, mas também de serem ouvidos
e respeitados por elas (por mais ultrapassadas e ultrajantes que estas
pareçam). (RAJAGOPALAN, 2013, p. 22).

Assim, vemos que, em todos os modos de gestão, as pessoas envolvidas devem ser ouvidas, independentemente do conhecimento teórico sobre língua e de seu posicionamento. Vale salientar que o autor trata do que seria, em sua opinião, o ideal na tomada de decisões em se tratando de língua, contudo sabemos, obviamente, que nem todos possuem os mesmos direitos para decidir políticas linguísticas de grande alcance, como as que permeiam as políticas educacionais. Ainda em relação ao papel do linguista, o mesmo autor alerta que é muito fácil se equivocar e cair na armadilha de concluir que o linguista, por afirmar ter conhecimento científico sobre a linguagem, deve ter "a palavra final em matéria de política linguística. Às vezes, o equívoco é fruto de um descuido ou uma força de expressão". (RAJAGOPALAN, 2014, p. 81).

Para finalizar, lembramos que o fato de ser necessário que todos sejam ouvidos na tomada de decisões em relação a políticas linguísticas não é algo que pode ser encontrado na trajetória das políticas linguísticas no Brasil, quando tratamos de políticas in vitro. Para melhor compreender essas questões, passaremos agora a discutir a relação entre as políticas linguísticas e o ensino de línguas no Brasil.

\section{O ENSINO DE LÍNGUAS NO BRASIL: POLÍTICAS LINGUÍSTICAS POSTAS EM PRÁTICA}

Nesse tópico, buscamos apresentar uma incursão histórica das políticas linguísticas em nosso país, desde a colonização até os tempos atuais, abordando, principalmente, as políticas in vitro, sem desconsiderar o fato de que, conforme veremos, muitas deles entraram em choque com as políticas in vivo. 
A primeira fase das políticas linguísticas no Brasil é chamada por Altenhofen (2013) de fase "virgem" do período colonial, pois se caracteriza por uma postura mais passiva em relação às línguas indígenas, momento esse em que ocorre o domínio e a difusão da língua geral - o nheengatu. Salientamos que, de acordo com Maher (2013), no processo de catequização dos indígenas, os jesuítas tinham como projeto utilizar o latim como língua de catequese, porém a imensa diversidade linguística do Brasil inviabilizava esse uso. Desse modo, é que se vê a necessidade de utilizar a língua geral, a qual passou a ser utilizada como uma espécie de língua franca por indígenas, negros e missionários (MAHER, 2013), considerando que ela já assumia essa função no contato entre indígenas que falavam diferentes línguas, sendo ainda é usada no norte do Brasil.

Apesar de esse uso ser interessante para o projeto de evangelização dos jesuítas, passou a ser um problema para o governo lusitano quando este buscou instaurar a língua portuguesa como a língua nacional do Brasil. Por isso, em1758, logo após a expulsão dos jesuítas, “o Marquês de Pombal torna público o Diretório dos Índios, documento no qual se proibia o ensino de línguas indígenas, particularmente o nheengatu, e se estabelecia o português como língua oficial do país” (MAHER, 2013, p. 122).

Há que se salientar que, de acordo com a mesma autora, a política pombalina teve um papel de extrema importância para a busca da "unificação" linguística no Brasil, porém a hegemonia da língua portuguesa só se estabeleceu mais tarde, em 1850, uma vez que até essa data o uso da língua portuguesa, na prática, estava subordinada ao uso do nheengatu. Entre os motivos dessa subordinação está a resistência empreendida por meio da Revolta da Cabanagem (1835-1845), conflito esse em que cerca de quarenta mil falantes de nheengatu foram mortos por se rebelarem contra a dominação dos colonizadores, segundo Bessa Freire (1983), reduzindo muito o número de falantes. Percebemos, nesse contexto, um importante papel desempenhado in vivo por aqueles que não concordavam com as políticas in vitro do Estado, um papel de resistência.

Nesse mesmo sentido, Oliveira (2002) afirma que não se pode imaginar que leis como Diretório dos Índios tenham sido "obedecidas" pela população, uma vez que houve muita resistência "contra as políticas de homogeneização e glotocídio, numa verdadeira guerra de línguas" (OLIVEIRA, 2002, p. 85), conforme já apontado por Maher (2013). Percebendo as consequências bastante sérias que sofreram aqueles que se rebelaram contra as políticas homogeneizadoras, relembramos a orientação de Calvet (2002), quando esse diz que não 
devemos deixar com que os outros tomem decisões sobre língua por nós, a fim de que percebamos o que isso pode significar.

Para se ter uma dimensão mais precisa do que representou na prática a política de Pombal, vejamos alguns números trazidos por Mattos e Silva (2004). Segundo a autora, no Brasil, eram usadas mais de mil línguas autóctones no início da colonização,

das quais $85 \%$ foram dizimadas no período colonial, e continuam a desaparecer, porque isso aconteceu com os seus falantes - dos cinco milhões em 1500, variados cultural e linguisticamente em mais de 1.500 povos, calculam-se 800.000 indivíduos no final da colonização, talvez 300.000 no final do império, cerca de 262.000 hoje. (MATTOS E SILVA, 2004, p. 37).

Dessa forma, vemos que não podemos desprezar as consequências de uma política como a de Pombal, pois os números nos mostram o quanto ela conseguiu atingir os seus objetivos. Obviamente, em relação à orientação de Calvet (2002) trazida acima, não estamos querendo dizer que não devamos lutar pelos nossos direitos linguísticos, buscando com que nos ouçam ao tomar decisões sobre questões que nos afetam diretamente. Porém, gostaríamos de enfatizar que, mesmo que se tenha esse engajamento, não é uma tarefa fácil, considerando que, como vimos na política discutida acima, as relações verticais de poder definiram quem deveria obedecer. Por outro lado, também enfatizamos o papel das lutas contra essa política para que hoje ainda tenhamos línguas indígenas sendo usadas.

Sobre essa questão da resistência a políticas linguísticas, Rajagopalan (2005), ao tratar da realidade do Inglês no mundo atual, discutindo formas de resistência que estejam entre o enfrentamento quixotesco e o derrotismo covarde, explica que, no lugar de uma subserviência consciente e passiva, é possível adotar uma resistência consciente e consequente. Em outras palavras, para o autor, quando há a imposição de uma língua, pode ser adotada uma postura que permita utilizar essa língua para servir aos interesses dos agora falantes dessa língua e não dos dominadores. Avaliamos de maneira positiva essa orientação de Rajagopalan (2005), de modo a complementar e a problematizar a fala de Calvet (2002) trazida anteriormente.

Ainda em relação às línguas indígenas, Oliveira (2002) afirma que

A política linguística do estado sempre foi a de reduzir o número de línguas, num processo de glotocídio (assassinato de línguas) através [...] de sua substituição pela língua portuguesa. A história linguística do Brasil poderia ser contada pela sequência de políticas linguísticas homogeinizadoras e repressivas e pelos resultados que alcançaram: somente na primeira metade deste século, segundo Darcy Ribeiro, 67 línguas indígenas desapareceram no Brasil - mais de uma por ano, portanto (RODRIGUES, 1993, p. 23). Das 
1.078 línguas faladas no ano de 1500 ficamos com cerca de 170 no ano 2000. (OLIVEIRA, 2002, p. 84).

Vemos, com isso, que não foi só com a política pombalina que se buscou o estabelecimento de um Estado monolíngue, pois, muito depois do Diretório dos Índios, ainda há línguas indígenas desaparecendo. Além disso, pelas palavras de Oliveira (2002), percebemos que houve uma sequência de políticas semelhantes.

Antes de discutirmos as políticas em relação aos imigrantes, não podemos deixar de salientar que os negros escravizados também sofreram com políticas de proibição do uso de suas línguas. Sobre essa questão, Maher (2013), baseando-se em Petters (2006), afirma que é difícil de estimar o número de línguas africanas faladas no Brasil após o processo de escravização, pois a estratégia de Portugal foi a de misturar as diferentes etnias para evitar a concentração de africanos com a mesma etnia antes mesmo de os escravizados terem sido forçados a partir da África. Ainda segundo a mesma autora, estariam cerca de 200 a 300 línguas envolvidas no tráfico. Em relação às línguas africanas, segundo Altenhofen (2004), é possível concluir que a perda dessas línguas, "não obstante a contribuição inexorável dos africanos à constituição da população e da cultura brasileiras, constitui outra evidência da força monolingualizadora do português como língua nacional”. (ALTENHOFEN, 2004, p. 84).

Essa mesma força monolingualizadora podemos perceber ao analisarmos as políticas linguísticas em relação às línguas de imigração. Já no período de imigração europeia, que complexificou ainda mais a situação linguística do Brasil, pode-se ver o silêncio e a indiferença do Estado em relação a essas línguas, mas também já se pode "notar manifestações de preocupação com a ‘assimilação' dos novos 'inquilinos””. (ALTENHOFEN, 2013, p. 108). É importante frisarmos que essa omissão que nos soa aparentemente como uma ausência de uma política linguística de Estado é, na opinião de Maher (2013), uma política linguística de Estado.

Essa preocupação de que fala Altenhofen (2013) parte de uma constatação óbvia, a de que "esses imigrantes para cá vieram, trazendo na bagagem suas línguas maternas”. Assim, “o plurilinguismo em nosso país é [...] reavivado.” (MAHER, 2013, p. 123). Considerando o ponto de partida das políticas linguísticas relacionadas às línguas indígenas e às línguas africanas, podemos concluir que o Estado não viu com bons olhos o uso das línguas de imigração dentro do território brasileiro, o qual, para o governo, deveria ser monolíngue a fim 
de garantir o sentimento de identidade nacional única partindo do princípio "Um povo, uma língua, uma nação" (RAJAGOPALAN, 2003).

Isso porque, apesar de a identidade, segundo Silva (2000), não ser fixa, definitiva ou homogênea, buscava-se, por meio da homogeneização da língua, que as identidades e identificações fossem controladas, de forma a servirem aos projetos de criação do Estado moderno. Porém, como ressalta o autor, a identidade é uma construção, sendo contraditória, fragmentada e sempre inacabada, assim, a identidade, e mesmo a identidade nacional, não pode ser delimitada por meio de uma fronteira que demarcaria o limite entre um Estado e outro, nem pelo uso de uma mesma língua.

Contudo, a partir desse ideal de identidade baseada em uma essência, "ocorrem as primeiras tentativas de assimilação do que é diverso em prol de uma ideia romântica de nação pautada no uso de uma única língua [...]”. (ALTENHOFEN, 2013, p. 108). De acordo com o autor, esse período republicano teve como grande característica o forte nacionalismo que estava na base da exaltação do tripé "índio-negro-branco" representando a identidade nacional brasileira. Salientamos que os imigrantes estavam excluídos dos "brancos", uma vez que estes seriam os colonizadores portugueses. Assim, esse ideal de nação mobilizou políticas linguísticas repressoras do uso das línguas de imigração.

Essa política também se destacou no período entre as duas Guerras Mundiais, pois as questões relacionadas ao nacionalismo, ao vínculo por parte de imigrantes com os países de onde emigraram, preocupavam os governantes. Assim,

os imigrantes - chegados principalmente depois de 1850 - e seus descendentes passaram por violenta repressão linguística e cultural - já que a língua naturalmente é parte da cultura. O Estado Novo (1937-1945), regime ditatorial instaurado por Getúlio Vargas, marca o ponto alto da repressão às línguas alóctones, através do processo que ficou conhecido como 'nacionalização do ensino' e que pretendeu selar o destino das línguas de imigração no Brasil. (OLIVEIRA, 2002, p. 86).

$\mathrm{Na}$ prática, de acordo com o mesmo autor, isso acarretou a ocupação e a desapropriação de escolas comunitárias, o fechamento de gráficas de jornais escritos em alemão e italiano, a perseguição, a prisão e a tortura de pessoas simplesmente por elas utilizarem suas línguas maternas, seja em público ou mesmo dentro de suas próprias casas, "instaurando uma atmosfera de terror e vergonha que inviabilizou em grande parte a reprodução dessas línguas.”. (OLIVEIRA, 2002: 86). 
Em Santa Catarina, além da política de Vargas, houve também as ações movidas na gestão do governador Nereu Ramos, o qual, segundo Oliveira (2002), chegou a montar campos de concentração, chamados de "área de confinamento" para descendentes de alemão. Além disso,

[...] a escola da 'nacionalização' estimulou as crianças a denunciar os pais que falassem alemão ou italiano em casa, criando sequelas psicológicas insuperáveis para esses cidadãos que, em sua grande maioria, eram e se consideravam brasileiros, ainda que falando alemão. (OLIVEIRA, 2002, p. 87).

Conforme podemos perceber, na maioria das vezes, vemos exemplos de ações contra as línguas alemã e italiana, pois sofreram ações mais severas do Estado devido à situação mundial em meio à Guerra. Sobre as políticas linguísticas voltadas às línguas de imigração, podemos concluir que "Historicamente, [...] a política linguística para essas populações de imigrantes alternou entre momentos de indiferença e de imposição severa de medidas prescritivas e proscritivas." (ALTENHOFEN, 2004, p. 83).

Já no período Pós-guerra, Altenhofen (2013) chama a atenção para o silêncio e a superação das experiências traumáticas ocorridas no período anterior, explica também que a escola ficou alheia às línguas de imigração, de modo a ignorar "suas potencialidades para a educação e seu valor para a identidade local. Não se tem notícia de nenhum projeto de educação que incorporasse o bilinguismo local às práticas ou reflexões pedagógicas". (ALTENHOFEN, 2013, p. 109). Em outras palavras, Oliveira (2005) nos diz, de maneira bastante enfática, que "as escolas costumam ser o túmulo das línguas". (OLIVEIRA, 2005, p. 89). Há uma ressalva a ser feita em relação ao fato de se afirmar que a escola ficou alheia às línguas de imigração, pois a escola não agiu apenas desconsiderando a língua que o aluno falava, mas, assim como no Estado Novo, agiu como um mecanismo de Estado no processo de silenciamento das línguas estrangeiras (STÜBE NETTO, 2008), de modo que

A partir de uma apurada análise sócio-histórica, verificam-se implicações
advindas do processo de nacionalizar integralmente o ensino primário de
todos os núcleos de origem estrangeira e seus efeitos na constituição de um
ideal da unidade linguística, ao lado da unidade política e da coesão de
interesses em torno do Estado Nacional. (STÜBE NETTO, 2008, p. 187)

Tendo em vista todo esse processo, Maher (2013) nos leva a refletir sobre o contexto atual, quando explica que, se o Estado pode ser acusado pelos atos de repressão cometidos contra os imigrantes que aqui chegaram no final do século XIX e no início do século XX, 
agora ele é acusado "pela sua omissão com relação às línguas de seus imigrantes mais recentes.” (MAHER, 2013, p. 124). A essa constatação, acrescentamos que o Estado também é omisso com relação às línguas faladas pelos descendentes dos imigrantes que passaram por todas as políticas de monolinguismo adotadas pelo Estado Novo.

Para finalizar esse tópico, afirmamos que, a partir das políticas linguísticas listadas aqui de forma breve, é possível perceber que

poderíamos ter sido um país ainda muito mais plurilíngue, não fossem as repetidas investidas do Estado (e das instituições aliadas, ou ainda a omissão de grande parte dos intelectuais) contra a diversidade cultural e linguística. Essa mesma História nos mostra, entretanto, que não fomos apenas um país multicultural e plurilíngue: somos um país pluricultural e multilíngue, não só pela atual diversidade de línguas faladas no território, mas ainda pela grande diversidade interna da língua portuguesa aqui falada [...]. (OLIVEIRA, 2002, p. 88).

\section{PARA ALÉM DAS POLÍTICAS LINGUÍSTICAS EM PROL DO MONOLINGUISMO}

Pensar em políticas linguísticas da esfera in vivo é pensar em políticas linguísticas que podem agir no sentido oposto ao do monolinguismo, porém, dependendo do modo como se articulam, entendemos que elas podem contribuir para a perpetuação de uma visão de língua como única. Por isso, gostaríamos de abordar o que há para além dessas políticas que buscam a língua única.

Ao longo dessa discussão, foi possível notar como foi o processo de criação do mito do monolinguismo por parte do Estado, sempre por meio de ações violentas, as quais acabaram por interferir nas culturas e, por consequência, nas identidades daqueles que foram impedidos de fazer uso de suas línguas maternas. Lembramos que a criação do mito do monolinguismo e da nossa própria noção de língua não é um fato concluído, pois ocorre cotidianamente tanto na gestão in vivo como na gestão in vitro.

Nesse sentido, baseados em Pinto (2014), esclarecemos que esses discursos sobre língua, como sobre o mito do monolinguismo,

São discursos que lançam raízes profundas no nosso pensamento sobre língua no Brasil; sua profundidade se espalha no tempo, na história da formação das ideias, e no espaço, nas dependências e resistências a outras formas de pensar sobre e agir na língua. Com raízes no passado e muitas também no presente, esses discursos apresentam as características de serem muito repetidos e de apresentarem grande capacidade de controle de seus 
efeitos e de sua própria reprodução, ou seja, são discursos hegemônicos. (PINTO, 2014, p. 62).

Pela fala da autora, vemos que as raízes desses discursos estão no passado, mas é no presente que eles são reiterados, de forma a perpetuar uma visão de língua hegemônica. Por isso, podemos entender a fala de Anderson (2008), quando esse diz que, nas políticas de “construção da nação", é possível perceber "um autêntico entusiasmo nacionalista popular ao lado de uma instilação sistemática, e até maquiavélica, da ideologia nacionalista" por meio da “comunicação de massa, do sistema educacional, das regulamentações administrativas, e assim por diante." (ANDERSON, 2008, p. 164). Assim, podemos ver que muitas das políticas in vitro que buscam a língua única também são mantidas por ações de agentes de políticas linguísticas in vivo, que convivem lado a lado, reforçando certos consensos sobre língua que são repetidamente veiculados pela mídia e estão presentes nas salas de aula.

Entre os consensos sobre língua no Brasil que foram e são construídos por atos de fala reiterados trazidos por Pinto $(2012 ; 2014)$, destacamos a unidade linguística de nosso país, assim "uma enorme pluralidade de práticas linguísticas é subsumida como sendo a mesma língua apesar das diferenças regionais" (PINTO, 2012, p. 174), baseando-se na velha ideia enraizada no Romantismo alemão de que a homogeneidade linguística é sinônimo de uma homogeneidade de território (PINTO, 2012).

Apesar de sabermos como é difícil apresentar alternativas aos discursos hegemônicos que, por meio de atos de fala reiterados, vão cristalizando as visões sobre língua, acreditamos que, "Ao invés da ótica monolinguista, pautada na soberania e exclusividade da língua majoritária, coloca-se a alternativa mais adequada da postura plural e inclusiva". (ALTENHOFEN, 2013, p. 101).

Desse modo, também entendemos, a partir das discussões de Altenhofen (2013), que é errôneo pensar que, em se tratando de políticas linguísticas para línguas minoritárias, "a maioria não tem nada a ver com as minorias, quando as decisões sobre o que pode ou não e o que tem relevância ou não no espaço da diversidade partem primordialmente da ótica majoritária" (ALTENHOFEN, 2013, p. 99), ou seja, partem principalmente daqueles que detêm o poder, não necessariamente daqueles que estão em um maior número na sociedade. Um exemplo trazido pelo autor é o próprio Censo Demográfico de 2010, que, segundo ele, 
não partiu da perspectiva dos falantes de línguas minoritárias, uma vez que não trouxe a pergunta sobre "outras línguas faladas no lar" em se tratando das línguas de imigração ${ }^{6}$.

Além disso, o mesmo autor afirma que a maioria, entendida nem sempre como aquela parcela formada por mais da metade da população, mas sim como aquela com maior prestígio, deve ser alvo de políticas linguísticas, a fim de que sejam desenvolvidas competências plurilíngues e de "dar ouvidos" à diversidade linguística e cultural. Dessa forma, o autor acredita que promover na população monolíngue uma consciência plurilíngue é tão importante quanto defender o direito das comunidades que fazem uso de outras línguas e de outras variedades de determinada língua.

Essa perspectiva de "dar ouvidos" trazida por Altenhofen é explicada por ele da seguinte forma:

\begin{abstract}
A abordagem para uma política linguística voltada a essas línguas [todas as línguas] parte, assim, da pressuposição de que sua construção necessariamente é plural, porque plurais são as sociedades humanas e as situações de uso das línguas. Daí deriva a suposição de que uma política linguística plural implica a inclusão e o respeito à diversidade de línguas, não apenas no sentido de 'garantir voz' às diferentes comunidades linguísticas que co-habitam determinado espaço de legislação, como também, e, principalmente, no sentido de 'dar ouvidos' e incentivar o plurilinguismo como postura adequada para uma 'democracia cultural' [...] (ALTENHOFEN, 2013, p. 96).
\end{abstract}

Uma visão como essa está em acordo com o que outros autores aqui utilizados entendem como uma política linguística sadia, como Rajagopalan (2013), autor esse que entende que as políticas linguísticas devem ter como partícipes e como alvos os próprios cidadãos, pois é necessário que se parta da vontade do cidadão e que se dirija a ele.

Com essa percepção, Altenhofen (2013) acredita que muitos dos conflitos existentes em grupos linguísticos seriam evitados ou, pelo menos amenizados, pois esses derivam do equívoco de se delegar todas as responsabilidades relativas às línguas ao Estado ou à escola, entendida como um instrumento do Estado, "e supor equivocadamente que as ações individuais em relação a línguas não têm qualquer efeito sobre esses conflitos, que se acredita

\footnotetext{
${ }^{6}$ Uma ressalva a ser feita em relação ao Censo de 2010 diz respeito às línguas indígenas, pois, de acordo com Fraga et al (2014), há questões sobre "outras línguas faladas no lar" voltadas à questão indígena se o participante da pesquisa se "autodeclarar" ou se "considerar" indígena. Segundo as autoras, o "Censo de 2010 foi o primeiro da história brasileira para o qual os entrevistados responderam a questões sobre a) pertencimento étnico [...] e b) uso/não uso de língua indígena e portuguesa em domicílio". 156
} 
serem resolvidos exclusivamente por ações do poder público". (ALTENHOFEN, 2013, p. 104).

A Declaração Universal dos Direitos Linguísticos explica que a situação de cada língua é o resultado de múltiplos fatores diferentes, entre eles, podem-se citar os fatores político-jurídicos, ideológicos, históricos, econômicos, sociais, culturais e subjetivos (OLIVEIRA, 2003). Por isso, não podemos fechar os olhos para a relação que há entre esses fatores.

\section{CONSIDERAÇÕES FINAIS}

A partir dessa breve revisão de conceitos relativos às políticas linguísticas, que abordou as diferentes esferas de gestão, bem como noções de planejamento linguístico e de agente de políticas linguísticas, não há como não perceber que é fundamental olharmos para o uso da língua de uma forma crítica, buscando entender o porquê falamos determinada língua de determinado modo, uma vez que esse ideal de uso foi construído por políticas linguísticas sustentadas por atos de fala reiterados que agem no sentido de cristalizar determinadas visões sobre língua.

Além disso, ao analisarmos a relação entre as gestões in vivo e in vitro, que, para Calvet (2007), podem ser conflituosas, devemos ir além e entendermos que os agentes de políticas linguísticas também devem ser vistos como aqueles que, mesmo pertencendo à esfera das políticas in vivo e a comunidades minoritárias, podem agir em prol dessa estrutura que tolhe a autonomia daqueles que buscam fazer uso das suas línguas, como as línguas de imigração e indígenas, agindo segundo o ideal de monolinguismo.

Dessa forma, ao se olhar abertamente para o histórico das políticas linguísticas, é possível perceber como o Estado, por diversas vezes, utilizou-se da escola para colocar em prática suas políticas linguísticas que agiam no sentido de construir um ideal de nação que não deixava espaço para a diversidade. Ter em mente todas essas políticas é fundamental para que olhemos criticamente para o modo como a língua é ensinada na atualidade, para os currículos e para os documentos oficiais que norteiam o ensino, de modo a percebermos quais os discursos perpassam a noção de língua a ser trabalhada em sala de aula.

Finalizamos essa discussão afirmando, baseados em Oliveira (2002), que é urgente que o Estado Brasileiro veja "essa importante faceta da diversidade constitutiva do Brasil. A diversidade não é só racial, étnica, de gênero, regional, a diversidade também é linguística." (OLIVEIRA, 2009, p. 2). Assim, poderemos pensar em políticas linguísticas que vão muito 
além das políticas em prol do monolinguismo e que considerem o contexto na qual são postas em prática, tendo em vista os anseios e necessidades dos falantes. Além disso, a partir do conhecimento das diferentes ações do governo em relação às línguas faladas em nosso território, é possível que, como professores e pesquisadores de línguas, tenhamos uma maior consciência de nosso papel como agentes de políticas linguísticas que podem ou não contribuir para a manutenção do mito do monolinguismo, tendo em vista as consequências de nossas opções, principalmente para aqueles que fazem uso de línguas minoritárias. Dessa forma, é indispensável que o repensar de nossas visões sobre língua seja constante.

Recebido em: maio de 2015 Aprovado em: novembro de 2015 djanecorrea@uol.com.br guths.tais@gmail.com

\section{REFERÊNCIAS}

ALTENHOFEN, Cléo V. Bases para uma política linguística das línguas minoritárias no Brasil. In: NICOLAIDES, Christine, et al. Política e Políticas Linguísticas. Campinas: Pontes Editores, 2013. p.93-116

Política linguística, mitos e concepções linguísticas em áreas bilíngues de imigrantes (alemães) no Sul do Brasil. In: Revista Internacional de Linguística Iberoamericana (RILI), Frankfurt a. M., n. 1(3): 83-93, 2004.

BESSA FREIRE, José Ribamar. Da "fala boa" ao português na Amazônia brasileira. 2001. Disponível em: <http://www.taquiprati.com.br/arquivos/pdf/FalaboaVersao2001.pdf>. Acesso em: 10 de março de 2015.

ANDERSON, Benedict. Comunidades Imaginadas. São Paulo: Companhia das Letras, 2008.

CALVET, Louis-Jean. As políticas linguísticas. São Paulo: Parábola Editorial, IPOL, 2007.

. Sociolinguística: uma introdução crítica. Tradução de Marcos Marcionilo. São Paulo:

Parábola, 2002.

CORREA, Djane Antonucci (Org.). Política Linguística e Ensino de Língua. Campinas: Editora Pontes, 2014.

FRAGA, Letícia; TASSO, Ismara; KASTELIC, Eloá Soares Dutra. A realidade linguística das comunidades indígenas do Paraná. In: Comissão Universidade para os Índios (CUIA): Política pública de educação superior indígena no Paraná. Rio de Janeiro: FLACSO, 2014.

HARDY-VALLÉE, Benoit. Que é um conceito? São Paulo: Parábola Editorial, 2013. 
MAHER, Terezinha Machado. Ecos de resistência: políticas linguísticas e línguas minoritárias no Brasil. In: NICOLAIDES, Christine, et al. Política e Políticas Linguísticas. Campinas: Pontes Editores, 2013. p.117-134.

MATTOS E SILVA, Rosa Virgínia. Ensaios para uma sócio-história do português brasileiro. São Paulo: Parábola Editorial, 2004.

NICOLAIDES, Christine, et al. Política e Políticas Linguísticas. Campinas: Pontes Editores, 2013.

OLIVEIRA, Gilvan Müller. Brasileiro fala português: Monolinguismo e Preconceito Linguístico. In: SILVA, F. L.; MOURA, H. M. M. (Orgs.). O direito à fala: a questão do preconceito linguístico. Florianópolis: Insular, 2002. p. 83-92.

(Org.) Declaração universal dos direitos linguísticos: novas perspectivas em política linguística. Campinas: Mercado de Letras, 2003.

. Línguas como patrimônio imaterial. 2009. Disponível em: http://www.ipol.org.br/ler.php?cod=281

. Política Linguística na e para além da Educação Formal. Estudos Linguísticos XXXIV, p. 87-94, 2005, p.87-94.

. Prefácio. In: CALVET, Louis-Jean. As políticas linguísticas. São Paulo: Parábola Editorial: IPOL, 2007. p. 7-10.

PINTO, Joana Plaza. Hegemonias, contradições em discursos sobre língua no Brasil. In.: CORREA, Djane Antonucci (Org.). Política Linguística e Ensino de Língua. Campinas: Editora Pontes, 2014. p.59-72.

. Modernidade e diferença colonial nos discursos hegemônicos sobre língua no Brasil. Muitas vozes, Ponta Grossa, v.1, n.2, p. 171-180, 2012.

RAJAGOPALAN, Kanavillil. A geopolítica da língua inglesa e seus reflexos no brasil: por uma política prudente e propositiva. In: LACOSTE, Yves (Org.). A Geopolítica do Inglês. São Paulo - SP: Parábola, 2005, p. 135-159.

. O professor de línguas e a suma importância do seu entrosamento na política linguística do seu país. In: CORREA, Djane Antonucci (Org.). Política Linguística e Ensino de Língua. Campinas: Editora Pontes, 2014. p.75-84.

. Política Linguística: do que é que se trata, afinal? In: NICOLAIDES, Christine, et al. (Org.) Política e Políticas Linguísticas. Campinas: Pontes Editores, 2013. p.19- 42.

. Por uma linguística crítica: linguagem, identidade e a questão ética. São Paulo: Parábola Editorial, 2003.

SILVA, Tomaz Tadeu. A produção social da identidade e da diferença. In: SILVA, Tomaz Tadeu (Org.) Identidade e Diferença: a perspectiva dos Estudos Culturais. Petrópolis: Vozes, 2000. p. 73102.

STÜBE NETTO, Angela Derlise. Tramas da subjetividade no espaço entre-língua: narrativas de professores de língua portuguesa em contexto de imigração, 2008. Tese (Doutorado em Linguística Aplicada). Universidade Federal de Campinas. Campinas, SP: 2008. 